\title{
Seasonal Variations in Haematological Parameters and Body Composition of Labeo rohita (Rohu) and Cirrhinus mrigala (Mrigal Carp) in River Indus, District Dera Ismail Khan, Pakistan
}

\author{
Syed Sikandar Habib ${ }^{1}$, Francesco Fazio ${ }^{2, *}\left(\mathbb{D}\right.$, Saira $\mathrm{Naz}^{3}$, Francesca Arfuso ${ }^{2}$, \\ Giuseppe Piccione2, Hameed Ur Rehman ${ }^{4}$, Wali Muhammad Achakzai ${ }^{5}$, \\ Muhammad Nazir Uddin ${ }^{6}$, Khalid Hussain Rind ${ }^{7}$, Nadir Ali Rind ${ }^{7}$
}

\author{
${ }^{1}$ University of Sargodha Punjab, Department of Zoology, Pakistan \\ ${ }^{2}$ University of Messina, Department of Veterinary Sciences, Polo SS Annunziata, 98168 Messina, Italy \\ ${ }^{3}$ University of Lahore Sargodha Campus Punjab, Institute of Molecular biology and Biotechnology, Pakistan \\ ${ }^{4}$ Kohat University of Science and Technology, Department of Zoology, KP, Pakistan \\ ${ }^{5}$ University of Baluchistan, Department of Zoology, Baluchistan, Pakistan \\ ${ }^{6}$ University of Swat, Center of Biotechnology and Microbiology, KP, Pakistan \\ ${ }^{7}$ Shaheed Benazir Bhutto University, Department of Molecular Biology and Genetics, Sindh, Pakistan
}

\section{How to cite}

Habib, S.S., Fazio, F., Naz, S., Piccione, F.A.G., Rehman, H.U., Achakzai, M.N.U., Rind, K.H. \& Rind, A.R. (2021). Seasonal variations in haematological parameters and body composition of Labeo rohita (Rohu) and Cirrhinus mrigala (Mrigal carp) in River Indus, District Dera Ismail Khan, Pakistan Turkish Journal of Fisheries and Aquatic Sciences, 21, 435-441. http://doi.org/10.4194/1303-2712-v21_7_01

\section{Article History}

Received 18 November 2021

Accepted 24 May 2021

First Online 26 May 2021

\section{Corresponding Author}

Tel.: +390906766516

E-mail: ffazio@unime.it

\section{Keywords}

Seasonal variation

Haematological

Proximate analysis

Labeo rohita

Cirrhinus mrigala

\begin{abstract}
The seasonal effect on haematology and body composition of Rohu and Mrigal carp were evaluated. Fifty-four fish of each species (Rohu length and weight $28.00 \pm 0.34 \mathrm{~cm}$ and $385 \pm 3.40 \mathrm{~g}$; Mrigal carp length and weight $29.48 \pm 0.24 \mathrm{~cm}$ and $393 \pm 5.48 \mathrm{~g}$ ) were collected from the Dera Ismail Khan. The values of WBCs $\left(9.31\right.$ and $\left.8.41 \times 10^{6} \mathrm{~mm}^{-3}\right)$, RBCs (2.37 and $\left.2.12 \times 10^{6} \mathrm{~mm}^{-3}\right), \mathrm{Hb}(9.58$ and 8.78$)$ and HCT (38.06 and $36.04 \%$ ) of Rohu and Mrigal carp were higher in summer whereas declined in winter $(P<0.05)$. The $\mathrm{MCV}, \mathrm{MCH}$ and $\mathrm{MCHC}$ of both species were higher $(\mathrm{P}<0.05)$ in winter, and decreased during summer. The moisture content of both Rohu and Mrigal carp was higher during winter followed by spring and lower in summer season. Lipid and protein content of both species were higher $(P<0.05)$ in summer and lower in winter. The moisture content, proteins and lipid were found higher in Rohu than Mrigal carp. According to the findings, it was concluded that the water quality parameters vary seasonally which in turn impacts on body physiology of fish species.
\end{abstract}

\section{Introduction}

From the very ancient time fish is considered one of the best source of protein that can be easily digested and have many therapeutics properties against many health issues like heart diseases, muscular degeneration and many problems associated with mental health (Begum et al., 2013; Dhaneesh et al., 2012). Proximate analysis of the fish shows that their body composition varies with the season, environment, age, sex, feeding habits and even with sexual changes and maturity (Roy \& Lall, 2006; Norouzi \& Bagheri, 2015).

Two important ecological parameters that are DO (Dissolve Oxygen) and the water temperature have a great influence on the body composition of the fish
(Mizanur et al., 2014). Understanding the seasonal effects on the composition and quality of the fish can help the consumer to select better fish species. Besides this, fish health can be assessed by evaluating the blood parameters of the fish (Fazio et al., 2016). Several studies have been carried out to assess the effect of the ecological change on the haematological profile of the fish. The low temperature can depress the immune system of the fish. Hence, their blood cell count and many other important characteristics vary with the seasonal change (Bett \& Vinatea, 2009).

The current study aimed to determine the variation in haematological parameters and body composition of fishes according to seasonal change. 


\section{Materials and methods}

\section{Water Parameters and fish sampling}

The water quality parameters including temperature, dissolved oxygen (DO) and $\mathrm{pH}$ were measured on monthly basis with different instruments such as temperature was measured with the help of a mercury thermometer, DO was measured using DO meter (Hanna Instrument HI9132) and $\mathrm{pH}$ was measured with a pH meter (Hanna Instrument HI221). The mean water quality of the site is given in Table 1.

Two commercially essential and widely cultured species of Pakistan, Labeo rohita (Rohu) and Cirrhinus mrigala (Mrigal carp) were selected for experiment and their sampling was done from the Indus River at Dera Ismail Khan District of Pakistan on monthly basis.

In each survey, six fish of each species (54 each; total 108) were captured with the help of local fishermen. Sampling was carried out from December 2018 to August 2019 covering three seasons including summer, spring and winter.

\section{Blood Sampling}

To determine the influence of seasonal variation on haematological parameters, of fish's blood sampling was performed by the caudal peduncle from each fish. Blood was poured into vials containing ethylenediamine-tetra-acetic acid (EDTA) as an anticoagulant agent. During sampling, fishes were not anesthetized because it may influence the blood indices (Torrecillas et al., 2011).

\section{Haematological Parameters}

The WBC and RBC count was performed through a Neubauer counting chamber according to the method of Schaperclaus et al. (1991). Haemoglobin (Hb) concentration was estimated according to the cyanmethemoglobin procedure proposed by Goldenfarb et al. (1971). In this procedure, a 0.02cc blood sample (non-clotted) was taken and dilute with $5 \mathrm{cc}$ of Drabkin solution and let stand for 10 minutes at $25^{\circ} \mathrm{C}$.

The amount of haemoglobin was calculated (against hemoglobin Standard) by reading absorbance at $540 \mathrm{~nm}$. Further, Hematocrit (HCT) was estimated through the process of sedimentation: briefly, $50 \mu \mathrm{l}$ of the heparinized blood was taken in the micro- hematocrit capillary and spun through the microhematocrit centrifuge for five minutes at $12000 \mathrm{rpm}$. Then hematocrit reader was used to count the value of $\mathrm{HCT}$. Further, the indices of the erythrocytes $(\mathrm{MCH}$, $\mathrm{MCHC}$ and $\mathrm{MCV}$ ) were calculated according to the procedure of the Dacie \& Lewis (1991).

Formula used for each indices was as follows:

$$
\begin{gathered}
\mathrm{MCH}=\frac{\mathrm{Hb}\left(\mathrm{g} \frac{\mathrm{d}}{\mathrm{L}}\right) \times 10 \text { microgram }}{\mathrm{RBC}\left(\frac{\text { millions }}{\text { microlitre }}\right)} \\
\mathrm{MCHC}=\frac{\mathrm{Hb}\left(\mathrm{g} \frac{\mathrm{d}}{\mathrm{L}}\right) \times 100 \mathrm{ml}}{\mathrm{HCT} \%} \\
\mathrm{MCV}=\frac{\mathrm{HCT} \% \times 10 \text { cubic microns }}{\mathrm{RBC}\left(\frac{\text { millions }}{\text { microlitre }}\right)}
\end{gathered}
$$

\section{Fish body composition}

Average total lengths of the sampled fish were noted, and they were within the range from $25-32 \mathrm{~cm}$ and their average weight was within the range of 320450 g. Fish proximate composition (moisture contents, protein concentration, lipid, ash content and dry matter contents) was determined by the standard method of AOAC (Association of Official Analytical Chemists, 2000) in triplicate to identify fish nutritional value with changing season.

Fishes were washed with distilled water and slaughtered. Scales and visceral organs were removed. To obtain a small piece of fillet fish was cut in length with the help of a sharp knife so that maximum fillet without backbone can be obtained.

\section{Moisture determination}

Moisture content was determined by drying the sample in the oven overnight. For this first petri dish was measured and then $5 \mathrm{~g}$ of wet sample was put in a petri dish and dried overnight in an oven at $105^{\circ} \mathrm{C}$. The next day sample weight was measured again and the process of drying in the oven repeat several times until a uniform weight is achieved.

The final weight was calculated with the help of the following formula (Haider et al., 2016).

$$
\text { Moisture }=\mathrm{W} 1-\mathrm{W} 2 / \mathrm{W} 1 \times 100
$$

W1 = initial weight of the sample

W2 = final weight of the sample

Table 1. Mean values ( \pm Standard Deviation) of water quality parameters measured during study period

\begin{tabular}{lccc}
\hline & \multicolumn{2}{c}{ Water quality parameters } \\
\cline { 2 - 4 } Seasons & $\mathrm{pH}$ & Temperature $\left({ }^{\circ} \mathrm{C}\right)$ & Dissolve oxygen $\left(\mathrm{mg} \mathrm{L}^{-1}\right)$ \\
\hline Summer & $7.1 \pm 0.058$ & $30 \pm 0.48$ & $6.5 \pm 0.18$ \\
Winter & $7.9 \pm 0.065$ & $21 \pm 0.50$ & $7.8 \pm 0.17$ \\
Spring & $7.0 \pm 0.025$ & $26 \pm 0.78$ & $7.0 \pm 0.35$ \\
\hline
\end{tabular}




\section{Protein determination}

In order to determine the protein content, $5 \mathrm{~g}$ of oven-dried sample were mixed with potassium sulphate + copper (digestion mixture). And then add $200 \mathrm{~mL}$ of concentrated $\mathrm{H}_{2} \mathrm{SO}_{4}$.

The mixture was heated on heating blocks white fumes formation id stop and solution became transparent. This is the indication that the digestion process is complete. Then after cooling the solution 60 $\mathrm{mL}$ of distilled water was added. Then with the help of the $45 \% \mathrm{NaOH}$ the $\mathrm{pH}$ was increased from 6.5 to 7 . After adding 6 drops of indicator into the solution and were mixed evenly, the flask was joined and combines with the condenser. And the tip of the condenser was dipped into the $\mathrm{HCl}$ and the solution was heated to evaporate the NH3. Then the final solution was titrated against sodium hydroxide (Pearson, 1999). Protein contents were identified by using the following formula:

$$
\text { Protein }=(A-B) \times N \times 14 \times 6.25 / W
$$

\footnotetext{
$A=$ volume of $0.2 \mathrm{~N} \mathrm{HCl}$ used in sample titration

$\mathrm{B}=$ volume of $0.2 \mathrm{~N} \mathrm{HCl}$ used in blank titration

$\mathrm{N}=$ normality of $\mathrm{HCl}$

$\mathrm{W}=$ sample weight

14 = atomic weight of nitrogen

6.25 = constant for nitrogen calculation
}

\section{Ash determination}

An amount of $5 \mathrm{~g}$ sample was taken into a crucible (already measured) and kept in the furnace for 6 hours at $550^{\circ} \mathrm{C}$. After the color change into white, the sample was measured again and the content at the bottom of the crucible is ash (Haider et al., 2016). formula:

Ash content was measured by the following

Ash\%= Weight of ash/ Weight of sample $\times 100$

\section{Lipids determination}

Lipid content was determined by using the soxhelt apparatus (ST243 Soxtec, FOSS, Hillerød, Denmark) following the method of the Bligh \& Dyer (1959).

Flask was filled with petroleum ether. After placing $5 \mathrm{~g}$ of sample in thimble the apparatus was run for 17 hours. After completion of the process, the flask was removed gently and dried on the heater.

When the sample starts oily smell the content was weighted while the fat content was measured by using the following formula:

\section{Fat=Weight off / Weight of sample $\times 100$}

\section{Statistical analysis}

The values are given as Mean \pm Standard Error of the mean (SEM).
Findings were checked for normal distribution with normality plots. One-way analysis of variance (ANOVA). After applying one-way ANOVA, the Tukey's HSD test was applied. $P$ values $<0.05$ are considered statistically significant.

\section{Results}

Effect of seasonal changes on haematological parameters of Labeo rohita and Cirrhinus mrigala

The haematological parameters such as White Blood Cells (WBCs), Red Blood Cells (RBCs), hemoglobin $(\mathrm{Hb})$, haematocrit (HCT), Mean Corpuscular Volume (MCV), Mean Corpuscular Hemoglobin (MCH) and Mean Corpuscular Hemoglobin Concentration (MCHC) were examined and the detail results are depicted in Table 2. The value of WBCs, RBCs, $\mathrm{Hb}$ and HCT was observed higher in the summer season followed by spring season respectively, and are significantly different $(P<0.05)$ in both species (Labeo rohita and Cirrhinus mrigala). While in between the species these values were higher in Labeo rohita as compared to Cirrhinus mrigala. While the values of $\mathrm{MCV}, \mathrm{MCH}$ and $\mathrm{MCHC}$ were higher $(\mathrm{P}<0.05)$ in winter season in both species followed by spring respectively. However, these values were observed higher in Cirrhinus mrigala than Labeo rohita.

\section{Effect of seasonal changes on biochemical parameters of Labeo rohita and Cirrhinus mrigala}

The biochemical constituents such as moisture, protein, lipid, ash contents and dry matter were recorded seasonally and the result is represented in Table 3. The moisture content of both species was recorded higher $(P<0.05)$ significantly in winter followed by spring season respectively. However, the moisture content of the body was more in Labeo rohita than Cirrhinus mrigala. Apart from this, the protein and lipid content of the body were significantly higher $(P<0.05)$ in the summer season followed by the spring season in both species, but their concentration was more in Labeo rohita. It was recorded that the body ash content of both species does not show any significant difference $(P>$ $0.05)$ and was the same in all the seasons.

\section{Discussion}

Deep knowledge of the fish body composition is advocated to utilize the better fish. Indeed, along with haematology, proximate is also considered as a valuable tool to assess the health and physiological condition of the fish (Silva \& Chamul, 2000; Fazio et al., 2019). The shallow water fishes are more prone to environmental dynamics as compared to deep water. Because the deep-water condition is more stable and constant as compared to shallow that rapidly changed due to environmental conditions which result in variation in temperature. Temperature is one of the most crucial 
factor of the environment, particularly for the aquatic organisms that change their physiological activities under different environmental stress (Wing et al., 2006; Pratt \& Fox 2002).

In the fish body, the moisture content is the most essential variable which varies seasonally. The variation of moisture content in the body of fish is linked to other biochemical variables such as lipid content. In all living bodies, the fluid is playing an essential role in transporting metabolites, nutrients etc. in the body parts. In the current study, the results revealed that the moisture content changes seasonally and was observed within a range from $70.81-74.76 \%$ in Labeo rohita and was $69.81-72.83 \%$ in Cirrhinus mrigala. However, the highest moisture content was observed in the winter season (Labeo rohita and Cirrhinus mrigala) and fat content was observed to be decreased in the winter season which showed an inverse relationship. This might be due to a decrease in temperature, low feeding rate and more demand for energy to keep the body temperature constant and to handle the food shortage in the winter season. Dinakaran et al. (2009) recorded similar findings while working on the Macrobrachium idea. In another study conducted by Bakhtyar \& Langer
(2016) worked on different sizes of Macrobrachium dayanum and their results revealed that the moisture in fish body increases in the winter season and is reverse of lipid content. A study reported on Atlantic bonito by Zaboukas et al. (2006) observed that with the maturation of gonads the moisture content increased in somatic tissues and was found lower in immature bonito. The protein was observed to increase during the summer season in both species followed by the spring season. The possible reason of the increased muscle protein might be due to the optimum range of temperature and more food availability as different zooplankton, phytoplankton and algal blooms. A similar study was reported on Aristeus antennatus and protein content was high in the summer and spring seasons (Rosa \& Nunes, 2003). According to Nargis (2006), a high amount of muscle protein was observed in the medium size of Anabas testudineus and was recorded a decrease in fish of increased age. In our study, the lipid content was recorded higher in the summer season and lower in winter in both species (Labeo rohita and Cirrhinus mrigala). The lipid changes are due to environmental conditions and the availability of food. In previous studies (Nargis, 2006; Jonsson \& Jonsson, 2005) it has

Table 2. Seasonal variation in haematological parameters of Labeo rohita and Cirrhinus mrigala collected from Indus River Dera Ismail Khan District

\begin{tabular}{|c|c|c|c|c|}
\hline \multirow{2}{*}{ Species } & \multirow{2}{*}{ Haematological parameters } & \multicolumn{3}{|c|}{ Seasons } \\
\hline & & Winter & Spring & Summer \\
\hline \multirow[t]{7}{*}{ Labeo rohita } & WBCs $\left(\times 10^{6} \mathrm{~mm}^{-3}\right)$ & $4.72 \pm 0.31^{c}$ & $6.07 \pm 0.20^{\mathrm{b}}$ & $9.31 \pm 0.31^{\mathrm{a}}$ \\
\hline & $\mathrm{RBCs}\left(\times 10^{6} \mathrm{~mm}^{-3}\right)$ & $1.25 \pm 0.04^{c}$ & $1.71 \pm 0.07^{b}$ & $2.37 \pm 0.08^{a}$ \\
\hline & $\mathrm{Hb}\left(\mathrm{g} \mathrm{dL}^{-1}\right)$ & $7.20 \pm 0.15^{c}$ & $8.69 \pm 0.18^{b}$ & $9.58 \pm 0.51^{\mathrm{a}}$ \\
\hline & HCT (\%) & $25.27 \pm 0.57^{c}$ & $31.16 \pm 1.02^{\mathrm{b}}$ & $38.06 \pm 1.08^{a}$ \\
\hline & $\operatorname{MCV}(f L)$ & $189.69 \pm 1.89^{a}$ & $189.49 \pm 3.92^{\mathrm{a}}$ & $170.13 \pm 3.02^{b}$ \\
\hline & $\mathrm{MCH}(\mathrm{Pg}$ cell-1) & $58.12 \pm 0.71^{\mathrm{a}}$ & $53.17 \pm 1.67^{b}$ & $42.79 \pm 1.31^{c}$ \\
\hline & MCHC (\%) & $28.75 \pm 0.41^{a}$ & $26.89 \pm 0.61^{b}$ & $24.31 \pm 0.35^{c}$ \\
\hline \multirow[t]{7}{*}{ Cirrhinus mrigala } & WBCs $\left(\times 10^{6} \mathrm{~mm}^{-3}\right)$ & $4.11 \pm 0.11^{c}$ & $5.09 \pm 0.80^{\mathrm{b}}$ & $8.41 \pm 0.51^{\mathrm{a}}$ \\
\hline & $\operatorname{RBCs}\left(\times 10^{6} \mathrm{~mm}^{-3}\right)$ & $1.37 \pm 0.03^{c}$ & $1.50 \pm 0.05^{b}$ & $2.12 \pm 0.02^{\mathrm{a}}$ \\
\hline & $\mathrm{Hb}\left(\mathrm{g} \mathrm{dL}^{-1}\right)$ & $6.80 \pm 0.22^{c}$ & $7.87 \pm 0.19^{b}$ & $8.78 \pm 0.71^{\mathrm{a}}$ \\
\hline & HCT (\%) & $24.31 \pm 0.83^{c}$ & $29.17 \pm 1.07^{b}$ & $36.04 \pm 1.08^{a}$ \\
\hline & $\mathrm{MCV}(\mathrm{fL})$ & $198.68 \pm 1.91^{\mathrm{a}}$ & $196.38 \pm 3.81^{\mathrm{a}}$ & $180.11 \pm 3.01^{\mathrm{b}}$ \\
\hline & $\mathrm{MCH}(\mathrm{Pg}$ cell-1) & $58.39 \pm 0.82^{a}$ & $54.16 \pm 1.92^{\mathrm{b}}$ & $44.61 \pm 1.42^{c}$ \\
\hline & $\mathrm{MCHC}(\%)$ & $29.65 \pm 0.51^{a}$ & $27.91 \pm 0.81^{\mathrm{b}}$ & $25.41 \pm 0.43^{c}$ \\
\hline
\end{tabular}

*Values in the same row of different superscript are significantly different $(\mathrm{P}<0.05)$

Table 3. Muscle composition of Labeo rohita and Cirrhinus mrigala collected from Indus River, Dera Ismail Khan District

\begin{tabular}{lcccc}
\hline \multirow{2}{*}{ Species } & Muscle composition & \multicolumn{3}{c}{ Seasons } \\
\cline { 3 - 4 } & & Winter & Spring & Summer \\
\hline Labeo rohita & Moisture & $74.76 \pm 1.21^{\mathrm{a}}$ & $72.09 \pm 1.68^{\mathrm{b}}$ & $70.81 \pm 2.07^{\mathrm{b}}$ \\
& Protein & $13.21 \pm 0.37^{\mathrm{d}}$ & $16.14 \pm 0.72^{\mathrm{c}}$ & $18.12 \pm 0.52^{\mathrm{a}}$ \\
& Lipid & $5.17 \pm 0.27^{\mathrm{c}}$ & $7.04 \pm 0.89^{\mathrm{b}}$ & $7.86 \pm 0.62^{\mathrm{a}}$ \\
Cirrhinus mrigala & Ash & $4.50 \pm 0.41^{\mathrm{b}}$ & $4.71 \pm 0.61^{\mathrm{b}}$ & $4.22 \pm 0.29^{\mathrm{b}}$ \\
& Moisture & $72.83 \pm 1.51^{\mathrm{a}}$ & $70.08 \pm 1.91^{\mathrm{b}}$ & $69.91 \pm 2.09^{\mathrm{b}}$ \\
& Protein & $13.10 \pm 0.77^{\mathrm{d}}$ & $15.18 \pm 0.91^{\mathrm{c}}$ & $17.13 \pm 0.71^{\mathrm{a}}$ \\
& Lipid & $5.19 \pm 0.39^{\mathrm{c}}$ & $7.06 \pm 0.41^{\mathrm{b}}$ & $7.91 \pm 0.41^{\mathrm{a}}$ \\
\hline
\end{tabular}

*Values in the same row of similar superscript are insignificantly different $(\mathrm{P}>0.05)$ 
been shown that the lipid or fat content was lower in adult specimens (Anabas testudineus and M. dayanum) because the adults are involved in breeding as their feeding intensity is lower and their metabolic rate is higher. According to Devi et al. (2015), the lipid content is involved in the maturation of gonads in adult fishes. Ash content in the present study does not show any significant difference seasonally in both species and there is no direct connection of ash with the breeding and feeding activities. Varghese \& Mathew (2016) conducted a study on Heteropneustes fossilis and Channa striata and observed no significant difference in ash content seasonally. A similar result was observed in another study while working on Trachurus mediterraneus (Tzikas et al., 2007).

In the natural habitat, fish species are pact with different factors such as varied water qualities, pollution, malnutrition, infection and disease and can adapt themselves to such environmental conditions by changing their physiological activities. Haematological study of the fishes has proved as a perfect tool for physiological indicators, through which fish health status can evaluate easily (Fazio, 2019). The present study revealed the seasonal variation effect on blood parameters of Labeo rohita and Cirrhinus mrigala. The haematological parameters such as WBCs, RBCs, $\mathrm{Hb}$ and $\mathrm{HCT}$ were recorded higher in both species during the summer season. It might be due to increased metabolic rate, optimum temperature and breeding activities lead to increase haematological parameters. These results are according to other studies conducted in the past while working on Capoeta trutta (Orun \& Erdeml, 2002), three Cyprinidae fish species (Orun et al., 2003; Pradhan et al., 2012) and Pleuronectes platessa (Preston, 1960). However, these haematological parameters were lower during the winter season which is due to decrease surrounding temperature and low food availability. Similar findings were observed by Adebayo et al. (2007) while working on Parachanna obscura. The RBC, $\mathrm{Hb}$ and HCT values in Labeo rohita and Cirrhinus mrigala were recorded higher in the summer season and are correlating with each other followed by spring and were found lower in the winter season. As we know, the fish is ectothermic and adapting the surrounding temperature of their habitat and at a higher temperature, their body metabolic activities increase and the amount of oxygen decreases in water at that period (Siddiqui and Nasim 1979) and due to hypoxia the $\mathrm{RBCs}$ and $\mathrm{Hb}$ in the body increases (Das et al., 2006). Also during the winter season, the RBC, $\mathrm{Hb}$ and $\mathrm{HCT}$ values decrease because, the fish environmental temperature is lower and the oxygen concentration is higher (Guijarro et al., 2003). In our study, WBCs count was recorded higher in the summer season and lower in winter. This indicates that in the summer season the WBCs are physiologically more capable of fish effective immunity (Santos et al., 2009). The MCH, MCV and MCHC in the current study increase during the winter season, whereas a decline has been observed in summer, these changes are probably related to environmental conditions and influence on body size. This is according to the results obtained by Orun et al. (2003).

\section{Conclusion}

According to the findings herein obtained it could be suggested that the exogenous factors especially seasonal variation affect the water parameters which in turn influence largely the haematological parameters of fish species investigated in the current survey. Also, the endogenous factors like reproductive period, fish length and weight affect the body composition of fishes like fat level, protein content etc. The blood profile and nutrients contents measured in both the species herein analyzed were significantly higher in the summer season, however, when comparing both species, it has been found that Labeo rohita had slightly higher protein and lipids content in summer as compared to any other season.

\section{Ethical Statement}

All applicable national guidelines for the care and use of animals were followed by the authors.

\section{Funding Information}

This research received no external funding.

\section{Author Contribution}

All authors have made substantial contributions to each step of experimental procedure and article preparation. The idea for the study was conceived by Syed Sikandar HABIB. The experiment was designed by Saira NAZ, Hameed Ur REHMAN, Wali Muhammad ACHAKZAI, Muhammad Nazir UDDIN, Khalid Hussain RIND, Nadir Ali RIND. The experiment was performed by Francesco FAZIO, Francesca ARFUSO and Giuseppe PICCIONE. The data were analyzed by Syed Sikandar HABIB, Saira NAZ, Hameed Ur REHMAN, Wali Muhammad ACHAKZAI, Muhammad Nazir UDDIN, Khalid Hussain RIND, Nadir Ali RIND. The article was written by Syed Sikandar HABIB. The last version of article was reviewed by Francesco FAZIO and Francesca ARFUSO.

\section{Conflict of Interest}

The authors declare that they have no conflict of interest.

\section{Acknowledgements}

The authors would like to thanks the Fisheries Department of Mianwali, for collaboration during the study. 


\section{References}

Adebayo, O.T., Fagbenro, O.A., Ajayi, C.B., \& Popoola, O.M. (2007). Normal haematological profile of Parachanna obscura as a diagnostic tool in aquaculture. International Journal of Zoological Research, 3, 193-199.

A.O.A.C., Association of Official Analytical Chemists. (2000). Official methods of analysis. Association of Official Analytical Chemists. 17th ed. Gaithersburg (MD): Association of Analytical Community.

Bakhtyar, Y., \& Langer, S. (2016). Seasonal variation in the proximate body composition of Macrobrachium dayanum (Henderson, 1893) (Decapoda, Caridea) from Gho-Manhasa stream, Jammu, North India. Acta Biologica Turcica, 29(3), 89-98.

Begum, A., Minar, M.H., Sarower-E-Mahfuj, M., \& Begum, M. (2013). Monthly variation of biochemical composition of gonia (Labeogonius) collected from Bangladeshi water. International Journal of Life Sciences Biotechnology and Pharma Research, 2(2), 227-232.

Bett, C., \& Vinatea, L. (2009). Combined effect of body weight, temperature and salinity on shrimp Litopenaeus vannamei oxygen consumption rate. Brazilian Journal of Oceanography, 57(4), 305-314.

Bligh, E.G., \& Dyer, W.J. (1959). A rapid method of total lipid extraction and purification. Canadian Journal of Biochemistry and Physiology, 37, 911-917.

Dacie, J.V., \& Levis, S.M. (1991). Practical Haematology. $11^{\text {th }}$ Edn. (pp. 633). Churchill Livingstone., London, UK.

Das, P.C., Ayyappan, S., \& Jena, J.K. (2006). Haematological changes in the three Indian major carps, Catla catla (Hamilton), Labeo rohita (Hamilton) and Cirrhinus mrigala (Hamilton) exposed to acidic and alkaline water pH. Aquaculture, 256, 80-87.

Devi, D.V.P., Hareesh, K., \& Reddy, M.S. (2015). Studies on the proximate composition of tropical freshwater prawn Macrobrachium rosenbergii. International Journal of Fisheries and Aquatic Studies, 3(1), 329-336.

Dhaneesh, K.V., Noushad, K.M., \& Kumar, T.T.A. (2012). Nutritional evaluation of commercially important fish species of Lakshadweep archipelago, India. Plos one, 7(9), e45439.

Dinakaran, G.K., Soundarapandian, P. \& Chandra, S.K. (2009). Proximate composition of edible palaemonid prawn Macrobrachium idae (Heller, 1862). Current Research Journal of Biological Sciences, 1(3), 78-82.

Fazio, F. (2019). Fish haematology analysis as an important tool of aquaculture. Aquaculture, 11, 8-15.

Fazio, F., Marafioti, S., Sanfilippo, M., Casella, S., \& Piccione, G. (2016). Assessment of immune blood cells and serum protein levels in Mugil cephalus (Linnaeus, 1758), Sparus aurata (Linnaeus, 1758) and Dicentrarchus labrax (Linnaeus, 1758) collected from the Thyrrenian sea coast, Italy. Cahiers De Biologie Marine, 57, 235-240.

Goldenfarb, P.B., Bowyer, F.P., Hall, T., \& Brosious, E. (1971). Reproducibility in the hematology laboratory: the microhematocrit determination. American Journal of Clinical Pathology, 56, 35-39.

Guijarro, A.I., Lopez-Patino, M.A., Pinillos, M.L., Isorna, E., De Pedro, N., Alonso-Gómez, A.L., Alonso-Bedate, M., \& Delgado, M.J. (2003). Seasonal changes in haematology and metabolic resources in the tench. Journal of Fish Biology, 62, 803-815.

Haider, M.S., Ashraf, M., Azmat, H., Khalique, A., Javid, A., Atique, U., \& Akram, S. (2016). Nutritive evaluation of fish acid silage in Labeorohita fingerlings feed. Journal of Applied Animal Research, 441, 158-164.

Jafri, A.K., \& Khawaja, D.K. (1968). Seasonal changes in the biochemical composition of the freshwater murrel, Ophicephalus punctatus Bloch. Hydrobiologia, 32(1), 206-218.

Jonsson, B., \& Jonsson, N. (2005) Lipid energy reserves influence life history decision of Atlantic salmon (Salmo salar) and brown trout (S. trutta) in fresh water. Ecology of Freshwater Fish, 14(3), 296-301.

Nargis, A. (2006). Seasonal variation in the chemical composition of body flesh of koi fish Anabas testudineus (Bloch) (Anabantidae: Perciformes). Bangladesh Journal of Scientific and Industrial Research, 41(3), 219-226.

Norouzi, M., \& Bagheri, M. (2015). The chemical composition of golden grey mullet Liza aurata in southern Caspian Sea during sexual rest and sexual ripeness. Aquaculture, Aquarium, Conservation \& Legislation, 8(4), 517-525.

Orun, I., Dorucu, M., \& Yazlak, H. (2003). Haematological parameters of three cyprinid fish species from Karakaya Dam Lake, Turkey. Journal of Biological Sciences, 3, 320328.

Orun, I., \& Erdeml, A.U. (2002). A study on blood parameters of Capoeta trutta (Heckel, 1843). Journal of Biological Sciences, 2, 508-511.

Pearson, D. (1999). Pearson's composition and analysis of foods. University of Reading. Reading, UK.

Pradhan, S.C., Patra, A.K., Sarkar, B., \& Pal, A. (2012). Seasonal changes in hematological parameters of Catla catla (Hamilton 1822). Comparative Clinical Pathology, 21, 1473-1481.

Preston, A. (1960). Red blood values in the plaice (Pleuronectes platessa L.). Journal of The Marine Biological Association of the United Kingdom, 39, 681-687.

Rosa, R., \& Nunes, M.L. (2003). Biochemical composition of deep-sea decapod crustaceans with two different benthic life strategies off the Portuguese south coast. Deep-Sea Research Part I: Oceanographic Research Papers, 50(1), 119-130.

Roy, P.K., \& Lall, S.P. (2006). Mineral nutrition of haddock Melanogrammus aeglefinus (L.): a comparison of wild and cultured stock. Journal of Fish Biology, 68(5), 14601472.

Santos, A.A., Egami, M.I., Ranzani-Paiva, M.J.T., \& Juliano, Y. (2009). Hematological parameters and phagocytic activity in fat snook (Centropomus parallelus): Seasonal variation, sex and gonadal maturation. Aquaculture, 296, 359-366.

Schaperclaus, W., Kulow, H., \& Schreckenbach, K. (1991). Hematological and serological technique. In: Kothelar, V.S. (Eds.) Fish Diseases (pp. 71-108) Gulab primlani, Oxonian Press, New Delhi, India.

Siddiqui, A.Q., \& Nasim, S.M. (1979). The haematology of mrigal, Cirrhina mrigala (Ham.) (Teleostei: Cyprinidae). Anatomischer Anzeiger, 146, 262-269.

Silva, J.J., \& Chamul, R.S. (2000). Composition of marine and freshwater finfish and shellfish species and their products. In: Martin, R.E., Carter, E.P., Flick, E.J., \& Davis, L.M. (Eds.) Marine and Freshwater Products Handbook (pp: 31-46) Technomic Publishing, Lancaster, Pennsylania, USA.

Torrecillas, S., Makol, A., Caballero, M.J., Montero, D., Gines, R., Sweetman, J., \& Izquierdo, M. (2011). Improved feed utilization, intestinal mucus production and immune parameters in sea bass (Dicentrarchus labrax) fed 
mannan oligosaccharides (MOS). Aquaculture Nutrition, 17(2), 223- 233.

Varghese, T., \& Mathew, S. (2016). Seasonal variations in the proximate composition of Asian stinging catfish Heteropneustes fossilis (Bloch, 1794) and Banded snakehead (Channa striata) (Bloch, 1793) collected from paddy field of Kerala. Trends in Fisheries Research, 5(3), 2319-4758.

Zaboukas, N., Miliou, H., Megalofonou, P., \& MoraitouApostolopoulou, M. (2006). Biochemical composition of the Atlantic bonito Sarda sarda from the Aegean Sea (Eastern Mediterranean Sea) in different stages of sexual maturity. Journal of Fish Biology, 69(2), 347-362.

Mizanur, R.M., Yun, H., Moniruzzaman, M., Ferreira, F., Kim, K.W., \& Bai, S.C. (2014). Effects of feeding rate and water temperature on growth and body composition of juvenile Korean rockfish, Sebastes schlegeli (Hilgendorf 1880). Asian-Australasian journal of animal sciences, 27(5), 690.

Tzikas, Z., Amvrosiadis, I., Soultos, N., \& Georgakis, S. (2007). Seasonal variation in the chemical composition and microbiological condition of Mediterranean horse mackerel (Trachurus mediterraneus) muscle from the North Aegean Sea (Greece). Food control, 18(3), 251257.

Wing, B.L., Masuda, M.M., \& Taylor, S.G. (2006). Time series analyses of physical environmental data records from Auke Bay, Alaska.

Pratt, T.C., \& Fox, M.G. (2002). Influence of predation risk on the overwinter mortality and energetic relationships of young-of-year walleyes. Transactions of the American Fisheries Society, 131(5), 885-898. 